\title{
An Online Survey to Determine Breeding Activities and Main Issues in Turkey's Beekeeping Enterprises
}

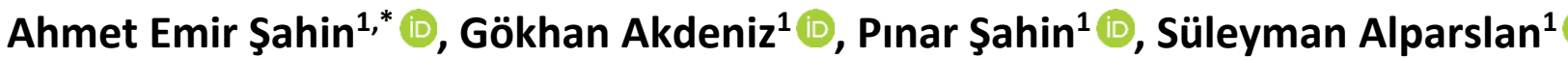

${ }^{1}$ Apiculture Research Institue, Ordu, Turkey

\section{Article History}

Received 15 December 2021

Accepted 29 December 2021

First Online 30 December 2021

\section{*Corresponding Author \\ Tel.: +905445240507 \\ E-mail: ahmetemir.sahin@tarimorman.gov.tr}

\section{Keywords \\ Beekeeping \\ Bee products \\ Breeding \\ Survey \\ Turkey}

\begin{abstract}
This study was conducted online survey between November 2019 and January 2020, with the objective of determining the production characteristics and sectoral issues of beekeeping enterprises in Turkey. According to the survey, the Black Sea region accounts for $28 \%$ of the total; the Central Anatolia region accounts for $18 \%$; the Marmara region accounts for $17 \%$; the Eastern Anatolia region accounts for $13 \%$; and the Aegean region accounts for $9 \%$. It was conducted with a total of 200 participants, $8.5 \%$ of which were beekeepers from the Mediterranean region and $6.5 \%$ from the Southeast Anatolia region. $82 \%$ of the participants are for income; $18 \%$ of them are involved in production activities for backyard purposes. The enterprises have an average of 140 colonies and produce $17.29 \mathrm{~kg}$ of honey per colony; $31.5 \%$ of the enterprises consider beekeeping to be their first job, and $49 \%$ use the migratory beekeeping model. $67 \%$ of them attended beekeeping classes. The enterprises collectively produce $90.5 \%$ extracted honey, $56.5 \%$ comb honey, and $23 \%$ natural honey comb. $37 \%$ of them work with Caucasian or crossbred bees, and $32.5 \%$ with Anatolian bees. It has been determined that $63.0 \%$ of enterprises meet their queen bee demands solely via their own operations, and $60.6 \%$ of enterprises are exposed to the varroa infection. According to our findings, one of the most important concerns for enterprises in the industry is marketing, which accounts for $24 \%$. Following issues, accommodation (17.7\%), diseases and pests (15.7\%), safety (15.7\%), transportation (10.4\%), and pesticide applications (7.1\%).
\end{abstract}

\section{Introduction}

Beekeeping is an important agricultural activity that produces products such as honey, pollen, royal jelly, beebread, and propolis, which have been used by people over the years for their food and pharmacological properties. Honey bees pollinate plants and ensure that agricultural products are greater in quantity and quality, in addition to the bee products they produce (Free, 1993). It is known that approximately 20000 of the more than 250000 flowering plant species spread in the world are visited by bees (Kaufman, 1989). 90 percent of the foodstuffs are acquired from 82 plant species and 63 (77\%) of these plant species require pollination by bees. Furthermore,
$1 / 3$ of human food is made up of plants that require bee pollination, either directly or indirectly (Güler, 2006). It is estimated that Turkey has 10000 natural plant species, 900 of which are indigenous, and 500 of these plants provide nectar and pollen. The plant diversity and vegetation in Turkey are highly diverse, and beekeepers may produce monofloral and polyfloral honeys nearly all year. In Turkey, roughly 81000 beekeeping enterprises produce 109330 tons of honey with 8128360 colonies (Anonim, 2021a). Turkey, which has the third-highest number of colonies in the world after India and China, also in second rank in terms of honey harvest (Anonim, 2021b). In 2020, 6011 tons of honeys were sold to numerous nations throughout the world, including Germany, the United States, and Saudi Arabia. Turkey 
covers $0.84 \%$ of global honey exports with this quantity (Anonim, 2021a). Although beekeeping in Turkey is in an increasing trend in terms of honey production and colony amount over the years, the low yield per colony, the problems experienced in the fight against diseases and pests, the insufficient variety of production, the instability of prices and the inability to reach the desired levels in the export of bee products can be shown among the biggest problems of the sector. Many local and national scholars have conducted scientific studies to pay attention to these issues (Kekeçoğlu \& Rasgele, 2013; Çelik \& Turhan, 2014; Kutlu, 2014; Emir, 2015; Akdeniz et al., 2015; Karahan \& Karaca, 2016; Kuvancı et al., 2017; Borum, 2017; Öztürk, 2017; Sert, 2017; Çevrimli \& Sakarya, 2018; Seğmenoğlu, 2018; Aktürk \& Aydın, 2019; Güneşdoğdu \& Akyol, 2019; Turhan, 2019; Tabur \& Gül, 2019; Kutlu \& Kılıç, 2020). The purpose of our study, which is one of the first online surveys conducted with beekeeping enterprises in Turkey, is to determine the general structure of backyard and income-oriented beekeeping enterprises at the national level, to define differences in colony management, and to reveal the present condition of beekeeping in Turkey from various perspectives.

\section{Materials and Methods}

An online survey was conducted with the Google online form between 8 November 2019 and 30 January 2020 in order to determine the production characteristics and sectoral problems of beekeeping enterprises in Turkey. Beekeepers were reached via online surveys and social media platforms such as Facebook, Twitter, and Instagram. Although 212 beekeepers took part in the study, only the surveys of 200 beekeepers were considered due to inadequate completing of the questions or inconsistencies in the replies. Following the completing the survey, the data collected were categorized and sorted, and qualitative data were applied to the remaining data using the Excel applications.

\section{Results and Discussion}

Regional distribution of beekeepers taking part in the survey; $28.0 \%$ Black Sea area; $18.0 \%$ Central Anatolia region; $17.0 \%$ Marmara region; $13.0 \%$ Eastern Anatolia region; 9.0\% Aegean region; 8.5\% Mediterranean region; and 6.5\% South East Anatolia region. 55 different provinces participated in our online survey study. These are the Black Sea provinces of Artvin, Giresun, Gümüşhane, Kastamonu, Ordu, Rize, Samsun, Sinop, Zonguldak, Bayburt, Bartın, Düzce, Trabzon; the Central Anatolia provinces of Ankara, Eskişehir, Kayseri, Konya, Nevşehir, Niğde, Yozgat, Karaman, Kırıkkale; the Marmara provinces of Balikesir, Bilecik, Bursa, Çanakkale, İstanbul, İzmit, Sakarya, Tekirdağ, Yalova; the Eastern Anatolia provinces of Elazığ, Erzincan, Erzurum, Muş, Van, Ardahan, and Iğdır; the Aegean provinces of Afyon, Aydın, İzmir, Kütahya, Manisa, Muğla; the Southeastern Anatolia provinces of Adıyaman, Gaziantep and Şanlıurfa; the Mediterranean provinces of Adana, Antalya, Hatay, Isparta, Mersin, Kahramanmaraş. The provinces with the largest involvement are 8\% Ordu, 7.5\% Konya, 4.5\% Erzurum, 4\% Istanbul, 4\% Artvin, 4\% Giresun, 4\% Adıyaman, 3\% Balıkesir, 3\% İzmit, 3\% Bursa, 3\% Ankara and 3\% İzmir.

The rate of interest in beekeeping among the young people is a significant factor in the long-term sustainability of beekeeping enterprises. In our study, the average age of the examined beekeeping enterprises was determined as 41.02 years (Table 1), and according to Güneşdoğdu and Akyol (2019) the resulting average age value was 47.77 in the Adana province; Onuç et al. (2019) reported 47 in Kemalpaşa district of İzmir province; Öztürk (2017) found 54 in Muğla; Söğüt et al. (2019) 47.3 in the province of Bingöl; Kadirhanoğulları et al. (2016) found 52 in Iğdır; Kekeçoğlu et al. (2014) reported 50.38 in Düzce; Kuvancı et al. (2017) 52.34 in the Eastern Black Sea Region; Aktürk and Aydın (2019) found 54.71 in Çanakkale; In the Aegean region of Çevrimli and Sakarya (2018), 50.08; It is seen that it is lower than the average age reported by Tabur and Gül (2019) as 53.19 in Uşak. Previous researches have found an age gap, which may be explained by the young population's participation in our online surveys, since they use social media significantly more frequently. In our study, income-oriented beekeeping enterprises had an average experience length of 13.07 years, whereas backyard beekeeping enterprises had an average experience length of 5.91 years (Table 1). The average experience period of the examined beekeeping enterprises was reported in previous studies; Onuç et al. (2019) 18.08 years; Öztürk (2017) 26 years; Söğüt et al. (2019) 18 years; Kadirhanoğulları et al. (2016) 20 years; Kuvancı et al. (2017) 24.28 years; Aktürk and Aydın (2019) 19.37 years; Çevrimli and Sakarya (2018) 17.52 years; Tabur and Gül (2019) were determined to be 18.47 years, less than their experience period.

Table 1. The average age and professional experience of the beekeeping enterprises surveyed

\begin{tabular}{lcccccc}
\hline & \multicolumn{2}{c}{ General } & $\begin{array}{c}\text { Income-oriented } \\
\text { enterprises }\end{array}$ & \multicolumn{2}{c}{$\begin{array}{c}\text { Backyard beekeeping } \\
\text { enterprises }\end{array}$} \\
\hline Age & $\mathbf{n}$ & $\begin{array}{c}\text { Average, } \\
\text { year }\end{array}$ & $\mathbf{n}$ & $\begin{array}{c}\text { Average, } \\
\text { year }\end{array}$ & $\mathbf{n}$ & $\begin{array}{c}\text { Average, } \\
\text { year }\end{array}$ \\
Beekeeping experience & 200 & 41.02 & 164 & 41.05 & 36 & 40.89 \\
\hline
\end{tabular}


In our study, the average colony number of income-oriented enterprises was calculated as 167 . On the other hand, Backyard beekeepers were calculated as 13.64 and, it was determined that the enterprises, in general, had an average of 140 colonies (Table 2). The average colony number of beekeepers in Adana was 293.21 (Güneşdoğdu and Akyol, 2019). The average number of colonies of enterprises in Adıyaman are 102.4 (Özbakır et al., 2016). The average colony number of beekeepers in Muğla province is 258 (Öztürk, 2017). In the Eastern Black Sea region, the average colony number is 101.56, and the highest average colony number is in Ordu with 228.41 colonies, and the lowest average colony number is in Gümüşhane with 56.33 colonies has been reported by (Kuvancl et al., 2017). Within the scope of our study, the average honey yield of income-oriented enterprises and backyard beekeepers were calculated as $17.41 \mathrm{~kg}$ and 16.75 respectively. In general, the average honey yield of the enterprises is $17.29 \mathrm{~kg}$ (Table 2). The average honey yield of income-oriented enterprises (95 enterprises) engaged in migratory beekeeping is $19.46 \mathrm{~kg}$. The average honey yield of backyard beekeepers (3 enterprises) is $19.00 \mathrm{~kg}$. The average honey yield of income-oriented enterprises (69 enterprises) that are not engaged in migratory beekeeping activities and backyard beekeepers (33 enterprises) was $14.58 \mathrm{~kg}$ and $16.55 \mathrm{~kg}$ respectively. In our study, it is seen that the average honey yield per colony of income and backyard enterprises and migratory and non-migratory beekeeping enterprises is higher than the Turkey average of $13.45 \mathrm{~kg}$. In a study conducted by Onuç et al. (2019) in the Kemalpaşa district of İzmir province, honey yield per colony was calculated as $19.27 \mathrm{~kg}$. Honey yield per colony of the enterprises in Adıyaman was calculated as $7.7 \mathrm{~kg}$ (Özbakır et al., 2016). Honey yield per colony in Yığılca district of Düzce province was calculated as $5.67 \mathrm{~kg}$ (Kekeçoğlu \& Rasgele, 2013). Honey yield per colony in Ordu, Artvin, Gümüşhane, Giresun, Bayburt, Trabzon and Rize provinces was 38.54 $\mathrm{kg}, 17.01 \mathrm{~kg}, 16.82,16.32 \mathrm{~kg}, 15.00 \mathrm{~kg}, 14.36 \mathrm{~kg}, 11.45$ $\mathrm{kg}$ respectively (Kuvancı et al., 2017). Honey yield per colony in Çanakkale was calculated as 16.24 kg (Aktürk \& Aydın, 2019). Honey yield per colony of beekeepers in Konya was calculated as $20-30 \mathrm{~kg}$ (Çelik \& Turhan, 2014). In the Hizan district of Bitlis province, it has been reported that $58 \%$ of beekeepers have a honey yield between $4-10 \mathrm{~kg}, 30 \%$ between $11-15 \mathrm{~kg}$, and $12 \%$ per colony of 3-6 kg (Kutlu et al., 2016). In Afyon province, $72.37 \%$ of the enterprises have a honey yield between $5-21 \mathrm{~kg}, 15.79 \%$ over $21 \mathrm{~kg}$, and 11.84 of them have honey yield per colony below $5 \mathrm{~kg}$ have been reported by (Karahan et al., 2019). It is seen that honey yields per colony of migratory beekeeping enterprises are higher than non-migratory beekeeping enterprises (Uzundumlu et al., 2011; Kekeçoğlu et al., 2014).

Table 2. The average number of colonies and honey yield of the beekeeping enterprises surveyed

\begin{tabular}{lccccccc}
\hline & \multicolumn{2}{c}{ General } & \multicolumn{2}{c}{$\begin{array}{c}\text { Income-oriented } \\
\text { enterprises }\end{array}$} & \multicolumn{2}{c}{$\begin{array}{c}\text { Backyard beekeeping } \\
\text { enterprises }\end{array}$} \\
\hline Number of colonies & $\mathbf{n}$ & Average & $\mathbf{n}$ & Average & $\mathbf{n}$ & Average \\
Honey yield $\mathbf{( k g )}$ & 200 & 140 & 164 & 167 & 36 & 13.64 \\
\hline
\end{tabular}

In our survey, 31.5 percent of the enterprises considered beekeeping to be their first job. The priority occupations of the remaining enterprises are $19 \%$ government workers, $11.5 \%$ farmers, $10.5 \%$ tradesmen and $27.5 \%$ of them are retired, self-employed, workers and private sector employees. $41.7 \%$ of backyard beekeeping enterprises are run by government workers, $41.7 \%$ by retirees, self-employed, workers, and private enterprise people (Table 3).

Table 3. The distribution of priority professions of the beekeeping enterprises studied

\begin{tabular}{|c|c|c|c|c|c|c|}
\hline & \multicolumn{2}{|c|}{ General } & \multicolumn{2}{|c|}{$\begin{array}{c}\text { Income-oriented } \\
\text { enterprises }\end{array}$} & \multicolumn{2}{|c|}{$\begin{array}{c}\text { Backyard beekeeping } \\
\text { enterprises }\end{array}$} \\
\hline & n & $\begin{array}{c}\text { Frequency, } \\
\% \\
\end{array}$ & $\mathbf{n}$ & $\begin{array}{c}\text { Frequency, } \\
\% \\
\end{array}$ & $\mathbf{n}$ & $\begin{array}{c}\text { Frequency, } \\
\% \\
\end{array}$ \\
\hline Beekeeper & 63 & 31.5 & 63 & 38.4 & - & - \\
\hline Farmer & 23 & 11.5 & 19 & 11.6 & 4 & 11.1 \\
\hline Government worker & 38 & 19 & 23 & 14.0 & 15 & 41.7 \\
\hline Tradesmen & 21 & 10.5 & 19 & 11.6 & 2 & 5.6 \\
\hline Other & 55 & 27.5 & 40 & 24.4 & 15 & 41.7 \\
\hline Total & 200 & 100 & 164 & 100 & 36 & 100 \\
\hline
\end{tabular}


In Adana province, $59 \%$ of beekeepers, $18 \%$ farmers, $12 \%$ retired, $7 \%$ tradesmen, $4 \%$ civil servants; In the province of Konya; $21 \%$ are beekeepers, $46 \%$ are farmers, $17 \%$ are retired, $9 \%$ are tradesmen and $7 \%$ civil servants (Karahan \& Karaca, 2016); When the activity areas of beekeepers in Muğla province are examined; $60 \%$ of them are only engaged in beekeeping, $15 \%$ of them are farming besides beekeeping, 7.5\% tradesmen, $15 \%$ retired, $2.5 \%$ civil servants (Öztürk, 2017); In the province of Konya, $91.11 \%$ of the enterprises owners are farmers, $4.45 \%$ are tradesmen, $2.22 \%$ are retired and $2.22 \%$ are workers, and in Konya, the enterprises are mostly engaged in beekeeping activities (Çelik \& Turhan, 2014); In the Hizan district of Bitlis province, apart from beekeeping, $6 \%$ of the enterprises are civil servants, $8 \%$ are farmers, $13 \%$ are tradesmen and $73 \%$ are workers (Kutlu et al., 2016); In a study conducted in the eastern Black Sea region, the ratio of enterprises that see beekeeping as the main source of income is $27.45 \%$, while the ratio of enterprises that see it as a source of secondary income is $72.55 \%$. Among the provinces in the region that consider beekeeping as the main source of income, Ordu province enterprises rank first with a rate of $50.62 \%$; $90.90 \%$ of the businesses that see it as the highest side income source are located in Gümüşhane (Kuvancı et al., 2017); In Iğdır province, $37.60 \%$ of beekeeping operators use beekeeping as their primary source of income, $43.50 \%$ as an additional income source and $18.90 \%$ for hobby purposes (Kadirhanoğulları et al., 2016).

In our survey, we discovered that $57.9 \%$ of incomeoriented enterprises and $8.3 \%$ of backyard beekeeping enterprises were involved in migratory beekeeping activities. In general, $49 \%$ of beekeeping enterprises use the migratory beekeeping concept (Table 4).

Table 4. Production model of the examined beekeeping enterprises

\begin{tabular}{lcccccc}
\hline & \multicolumn{2}{c}{ General } & \multicolumn{2}{c}{$\begin{array}{c}\text { Income-oriented } \\
\text { enterprises }\end{array}$} & \multicolumn{2}{c}{$\begin{array}{c}\text { Backyard beekeeping } \\
\text { enterprises }\end{array}$} \\
\hline Yes & $\mathbf{n}$ & $\begin{array}{c}\text { Frequency, } \\
\text { \% }\end{array}$ & $\mathbf{n}$ & $\begin{array}{c}\text { Frequency, } \\
\mathbf{\%}\end{array}$ & $\begin{array}{c}\mathbf{n} \\
\text { Frequency, } \\
\mathbf{\%}\end{array}$ \\
\hline No & 98 & 49.0 & 95 & 57.9 & 3 & 8.3 \\
\hline Total & 102 & 51.0 & 69 & 42.1 & 33 & 91.7 \\
\hline
\end{tabular}

An average of 2.93 income-oriented enterprises engaged in migratory beekeeping operations; however, backyard enterprises remain at an average of 2.00 points. 94.8\% of beekeepers in Adana (Güneşdoğdu \& Akyol, 2019); 89\% of the enterprises in Konya (Karahan \& Karaca, 2016); 53.5\% of the beekeepers in Adıyaman province (Özbakır et al., 2016); 96.05\% of enterprises in Afyon province (Karahan et al., 2019); 95\% of the beekeepers in the Eastern Black Sea region (Kuvancı et al., 2017); 87.36\% of beekeepers in Çanakkale (Aktürk \& Aydın, 2019); 31\% of beekeepers in Hizan district of Bitlis province (Kutlu et al., 2016); 39.2\% of the enterprises in Uşak (Tabur \& Gül, 2019) are engaged in migratory beekeeping activities. In Düzce, $46.8 \%$ of beekeepers are interregional, 9.00\% intra-provincial, $13.10 \%$ intra-district (Kekeçoğlu et al., 2014); In the Yığılca district of Düzce province, 19.1\% of them were migratory beekeepers (Kekeçoğlu \& Rasgele, 2013). The fact that the flowering periods of nectar and pollen source plants for honey bees in Turkey change due to altitude differences necessitate migratory beekeeping activities. In our study, the rate of enterprises engaged in migratory beekeeping, Güneşdoğdu and Akyol (2019), Karahan and Karaca (2016), Çelik and Turhan (2014), Karahan et al. (2019), Kuvancı et al. (2017), Aktürk and Aydın (2019), lower than the rates reported by; Kutlu et al. (2016), Tabur and Gül (2019), Kekeçoğlu and Rasgele (2013). It is thought that these differences are due to the fact that our study was carried out at the national level, and the literature studies were carried out at the specific regional or provincial level.

It was shown that $67 \%$ of the surveyed enterprises enrolled in technical education. The rate of involvement in technical education by income-oriented enterprises was found to be greater than that of backyard beekeeping-purpose enterprises (Table 5).

Table 5. The technical education status of the investigated beekeeping enterprises

\begin{tabular}{lcccccc}
\hline & \multicolumn{2}{c}{ General } & \multicolumn{2}{c}{$\begin{array}{c}\text { Income-oriented } \\
\text { enterprises }\end{array}$} & \multicolumn{2}{c}{$\begin{array}{c}\text { Backyard beekeeping } \\
\text { enterprises }\end{array}$} \\
\hline Yes & $\mathbf{n}$ & $\begin{array}{c}\text { Frequency, } \\
\text { \% }\end{array}$ & $\mathbf{n}$ & $\begin{array}{c}\text { Frequency, } \\
\text { \% }\end{array}$ & $\begin{array}{c}\text { Frequency, } \\
\mathbf{\%}\end{array}$ \\
\hline No & 134 & 67.0 & 114 & 69.5 & 20 & 55.6 \\
\hline Total & 66 & 33.0 & 50 & 30.5 & 16 & 44.4 \\
\hline
\end{tabular}


While it was reported that $16.3 \%$ of the beekeepers in Adıyaman took a 20-hour course, $40.7 \%$ took an 80 -hour course, and $36 \%$ did not attend any course or training (Özbakır et al., 2016), 45.01\% of the enterprises in Uşak were beekeeping. they gained professional knowledge from their courses and seminars (Tabur \& Gül, 2019); In Konya province, $57.11 \%$ of beekeepers attend beekeeping courses (Çelik \& Turhan, 2014); Among the sources of information about beekeeping in the province of Elazig, the rate of choosing beekeeping courses in the first degree was $49.2 \%$, while the rate of preference was found in the second place by $39.7 \%$ (Seven \& Yeninar, 2010). According to the information obtained from $27 \%$ of the beekeepers in Gaziantep, beekeeping courses are very effective on starting and learning beekeeping (Kutlu, 2014).

$42 \%$ of the enterprises surveyed produce just extracted honey, $8 \%$ produce only honeycomb, and $27 \%$ produce both extracted honey and honeycomb.
Cumulatively, $90.5 \%$ extracted honey, $56.5 \%$ honeycomb and $23 \%$ natural honeycomb are produced in the enterprises. Cumulatively, the enterprises produce $90.5 \%$ extracted honey, $56.5 \%$ honeycomb, and $23 \%$ natural honeycomb. Backyard beekeeping enterprises extracted honey and honeycomb production rates were found to be higher than incomeoriented enterprise rates. Cumulatively, $93.2 \%$ of income-oriented enterprises produce extracted honey, $58.5 \%$ honeycomb and $27.4 \%$ natural honeycomb. On the other hand, backyard enterprises produce $77.8 \%$ of extracted honey, $47.2 \%$ of honeycomb and $2.8 \%$ of natural honeycomb cumulatively. It is seen that incomeoriented enterprises produce more natural honeycomb than backyard-purpose enterprises (Table 6). In the Kemalpaşa district of İzmir province, $94.34 \%$ of beekeepers produce honeycomb, $22.64 \%$ natural honeycomb (Onuç et al., 2019). In addition, it has been reported that all beekeepers in Gaziantep produce honeycomb and extracted honey (Kutlu, 2014).

Table 6. Production types of the examined beekeeping enterprises

\begin{tabular}{lcccccc}
\hline & & General & $\begin{array}{c}\text { Income-oriented } \\
\text { enterprises }\end{array}$ & $\begin{array}{c}\text { Backyard } \\
\text { beekeeping } \\
\text { enterprises }\end{array}$ \\
\hline Extracted honey (EH) & $\mathbf{n}$ & Frequency, & $\mathbf{n}$ & Frequency,\% & $\mathbf{n}$ & Frequency,\% \\
Honeycomb & 84 & 42.0 & 65 & 39.6 & 19 & 52.8 \\
EH + Honeycomb & 16 & 8.0 & 8 & 4.9 & 8 & 22.2 \\
EH + Naturel Honeycomb & 54 & 27.0 & 46 & 28.0 & 8 & 22.2 \\
Honeycomb + Naturel Honeycomb & 3 & 1.5 & 3 & 1.8 & - & - \\
Honeycomb + EH + Naturel Honeycomb & 3 & 1.5 & 3 & 1.8 & - & - \\
\hline Total & $\mathbf{2 0 0}$ & 20.0 & 39 & 23.8 & 1 & 2.8 \\
\hline
\end{tabular}

In this study, $37.4 \%$ of the enterprises had mixed blossom honey, $15.3 \%$ thyme honey, $12.2 \%$ milkvetch honey, $12.2 \%$ chestnut honey, $10.6 \%$ pine honey. It was determined that $4.1 \%$ of them produced citrus honey and $8.3 \%$ of them produced other monofloral and polyfloral honeys, especially lavender, sunflower, cotton and oak. The ratio of mixed flower honey and monofloral chestnut honey produced by backyard beekeeping enterprises was found to be higher than that of income-oriented enterprises (Table 7).

Table 7. Distribution of honey produced in the examined beekeeping enterprises

\begin{tabular}{|c|c|c|c|c|c|c|}
\hline & \multicolumn{2}{|c|}{ General } & \multicolumn{2}{|c|}{$\begin{array}{c}\text { Income-oriented } \\
\text { enterprises }\end{array}$} & \multicolumn{2}{|c|}{$\begin{array}{c}\text { Backyard beekeeping } \\
\text { enterprises }\end{array}$} \\
\hline & n* & Frequency,\% & n* & Frequency,\% & $\mathrm{n}^{*}$ & Frequency,\% \\
\hline Blossom honey & 166 & 37.4 & 138 & 35.9 & 28 & 46.7 \\
\hline Milkvetch honey & 54 & 12.2 & 51 & 13.3 & 3 & 5.0 \\
\hline Thyme honey & 68 & 15.3 & 61 & 15.9 & 7 & 11.7 \\
\hline Pine honey & 47 & 10.6 & 44 & 11.5 & 3 & 5.0 \\
\hline Chestnut honey & 54 & 12.2 & 43 & 11.2 & 11 & 18.3 \\
\hline Citrus honey & 18 & 4.1 & 16 & 4.2 & 2 & 3.3 \\
\hline Other & 37 & 8.3 & 31 & 8.1 & 6 & 10.0 \\
\hline Total & 444 & 100 & 384 & 100 & 60 & 100 \\
\hline
\end{tabular}

${ }^{\star}$ Multiple responses were considered. 
In the Kemalpaşa district of İzmir province, 98.11\% of beekeepers produce pine honey (Onuç et al., 2019); beekeepers of Konya province concentrate on blossom, citrus and pine honey production and they go to the Mediterranean and Aegean regions, where pine honey is produced, especially at the end of August (Çelik \& Turhan, 2014); the plant diversity used by the migratory beekeepers to get nectar in the Yığılca district of Düzce; $46.7 \%$ chestnut, $26.6 \%$ chestnut and rhododendron, $13.3 \%$ rhododendron, $6.7 \%$ linden and $6.7 \%$ wildflower (Kekeçoğlu \& Rasgele, 2013). Migratory beekeepers in Ordu province stated that they carry out their beekeeping activities 20\% at Muş, 15\% at Erzincan, 12\% at Erzurum, 10\% at Yozgat, 9\% at Sivas, 7\% at Kars, 6\% at Kars, $3 \%$ at Hakkari, $1 \%$ at Çankırı, and $15 \%$ at more than one location to follow the blooming seasons, in addition $19 \%$ of the beekeepers in the Eastern Black Sea region stated that they produced honey in Erzurum province and $35 \%$ in the Eastern black sea location (Kuvancl et al., 2017).

It has been realized that $33.5 \%$ of the surveyed enterprises produce mainly pollen and honey, and $40 \%$ produce pollen, honey and other bee products. Together with honey, $19.0 \%$ of the enterprises are produced beeswax; $1.5 \%$ produced propolis, $1.0 \%$ produced royal jelly and $0.5 \%$ produced bee venom. It has been determined that the product variety of bee products in income-oriented enterprises is higher than in backyard enterprises. Together with honey, incomeoriented enterprises produced $73.6 \%$ of were pollen, $56.6 \%$ beeswax, $29.8 \%$ propolis, $7.8 \%$ royal jelly and $1.2 \%$ bee venom produced (Table 8 ).

Table 8. Production diversity of the examined beekeeping enterprises

\begin{tabular}{|c|c|c|c|c|c|c|}
\hline & \multicolumn{2}{|r|}{ General } & \multicolumn{2}{|c|}{$\begin{array}{l}\text { Income-oriented } \\
\text { enterprises }\end{array}$} & \multicolumn{2}{|c|}{$\begin{array}{c}\text { Backyard } \\
\text { beekeeping } \\
\text { enterprises }\end{array}$} \\
\hline & $\mathbf{n}$ & Frequency,\% & $\mathbf{n}$ & Frequency,\% & $n$ & Frequency,\% \\
\hline Pollen & 67 & 33.5 & 54 & 32.9 & 13 & 36.1 \\
\hline Propolis & 3 & 1.5 & 2 & 1.2 & 1 & 2.8 \\
\hline Beeswax & 38 & 19.0 & 30 & 18.3 & 8 & 22.2 \\
\hline Royal jelly (RJ) & 2 & 1.0 & 2 & 1.2 & - & - \\
\hline Bee venom & 1 & 0.5 & 1 & 0.6 & - & - \\
\hline Pollen + RJ & 1 & 0.5 & 1 & 0.6 & - & - \\
\hline Pollen+ Beeswax & 30 & 15.0 & 24 & 14.6 & 6 & 16.7 \\
\hline Pollen + Propolis & 13 & 6.5 & 9 & 5.5 & 4 & 11.1 \\
\hline RJ + Beeswax & 1 & 0.5 & 1 & 0.6 & - & - \\
\hline RJ + Propolis & 1 & 0.5 & - & - & 1 & 2.8 \\
\hline Beeswax + Propolis & 7 & 3.5 & 7 & 4.3 & - & - \\
\hline Pollen + RJ + Beeswax & 2 & 1.0 & 2 & 1.2 & - & - \\
\hline Pollen + RJ + Propolis & 2 & 1.0 & 2 & 1.2 & - & - \\
\hline Pollen + Beeswax + Propolis & 27 & 13.5 & 24 & 14.6 & 3 & 8.3 \\
\hline Pollen + RJ + Propolis + Beeswax & 4 & 2.0 & 4 & 2.4 & - & - \\
\hline $\begin{array}{l}\text { Pollen + Beeswax + Propolis + Bee venom } \\
+ \text { RJ }\end{array}$ & 1 & 0.5 & 1 & 0.6 & - & - \\
\hline Total & 200 & 100 & 164 & 100 & 36 & 100 \\
\hline
\end{tabular}

In the Kemalpaşa district of İzmir province, together with honey production, $94.34 \%$ of beeswax, $47.17 \%$ of pollen and $18.87 \%$ of propolis are produced by beekeepers (Onuç et al., 2019). In Adıyaman province, the income of the enterprises is obtained from honey, beeswax and pollen, respectively, and only $4.7 \%$ of the enterprises produce pollen (Özbakır et al., 2016). In Afyon province, $80.26 \%$ of beekeepers were produced beeswax, $63.16 \%$ pollen, $19.74 \%$ propolis, and $5.26 \%$ royal jelly (Karahan et al., 2019). In Çanakkale province, $35.63 \%$ beeswax, $34.48 \%$ pollen, $5.75 \%$ propolis and $4.59 \%$ royal jelly were produced by beekeepers (Aktürk \& Aydın, 2019). 6\% of beekeepers in
Ordu produce pollen. 7\% of enterprises in Giresun province produced pollen, propolis and royal jelly. 33\% of Trabzon province enterprises produce pollen and propolis. $17 \%$ of Artvin province enterprises produce pollen and propolis. $61 \%$ of Gümüşhane province enterprises produce pollen. $10 \%$ of the enterprises in Bayburt province produce pollen (Kuvancı et al., 2017). Beekeepers of Bitlis Hizan province produce $15 \%$ pollen and $3 \%$ royal jelly (Kutlu et al., 2016). It has been reported that $88.88 \%$ of the enterprises in Konya produce beeswax and $15.55 \%$ produce pollen (Çelik \& Turhan, 2014). It has been seen that the product diversity of the enterprises examined in our study is 
higher than in the previous studies. The reason for this high rate can be explained by the fact that the study was carried out at the national level and the use of online surveys.

The queen bee's quality is one of the most critical factors affecting a colony's productivity. $37 \%$ of the examined beekeeping enterprises were Caucasian or hybrid, 32.5\% Anatolian bee, 18\% Carniolan bee, $8.5 \%$ Belfast bee, $2.5 \%$ Muğla ecotype, $1 \%$ of beekeepers stated that they work with Italian bees and $0.5 \%$ with Yığılca ecotype. While income-oriented enterprises use 37.8\% Caucasian bees, 32.9\% Anatolian bees, and 15.9\% Carniolan bees, backyard enterprises use $33.3 \%$ Caucasian bees, $30.6 \%$ Anatolian bees, and $27.8 \%$ Carniolan bees (Table 9). According to Karahan and Karaca (2016), in the province of Adana; 56\% Hybrid bees (61\% Anatolian hybrid), 12\% Anatolian bee, 12\% Italian bee, while 37\% Caucasian bee and 35\% Hybrid bee (54.3\% Caucasian hybrid) were used in Konya. According to a study conducted in Adiyaman, $53 \%$ of the beekeepers work with Caucasian crossbreeds and $41 \%$ with Caucasian bee breeds (Özbakır et al., 2016). According to a research conducted by Karahan and Karaca (2019) in Afyon province, $47.37 \%$ of beekeepers use Anatolian bees, while $38.16 \%$ use hybrid bees (Aegean, Muğla, Italian, and Caucasian hybrids).
Kekecoğlu et al. (2014) stated that, native breeds appropriate to the region are used by $61.50 \%$ of beekeepers in Düzce, whereas Caucasian hybrids are used by 34.70 percent. According to Aktürk and Aydın (2019) the local bee breed is preferred by 41.38 percent of producers in Çanakkale, 37.93 percent prefer Anatolian bees, and 21.84 percent prefer Carniolan bees. In a study conducted by Akdeniz et al. (2015) in the province of Antalya, $36.84 \%$ of migratory beekeeping enterprises use Caucasian hybrids, $21.05 \%$ use Muğla bees, 5.26\% use Anatolian bees, and 36.84\% use multiple bee breeds in their enterprises, moreover in farms with mixed race colonies, $92.85 \%$ Caucasian crossbreeds, 14.29\% Anatolian Bees, $42.86 \%$ Belfast bees, 50\% Muğla bees, 35.71\% Italian bees, $21.43 \%$ Carniolan bees were reported. In a study conducted throughout Turkey, according to the information obtained from beekeepers, $65 \%$ hybrid honey bee, $12 \%$ Caucasian bee, 9\% Muğla bee, 6\% Anatolian bee, $4 \%$ Carniolan bee, 2\% Thrace bee and 1\% Buckfast are generally used (Emir, 2015). In our study, it is seen that the domestic and foreign queen bee races and ecotypes used in the production activities of the enterprises we examined are similar to the data obtained from the studies conducted in different geographical regions.

Table 9. The evaluated beekeeping enterprises' genotype distribution of reared queens

\begin{tabular}{lcccccc}
\hline & \multicolumn{2}{c}{ General } & \multicolumn{2}{c}{$\begin{array}{c}\text { Income-oriented } \\
\text { enterprises }\end{array}$} & \multicolumn{2}{c}{$\begin{array}{c}\text { Backyard beekeeping } \\
\text { enterprises }\end{array}$} \\
\hline & $\mathbf{n}$ & Frequency,\% & $\mathbf{n}$ & Frequency,\% & $\mathbf{n}$ & Frequency,\% \\
\hline Anatolia bee & 65 & 32.5 & 54 & 32.9 & 11 & 30.6 \\
Belfast bee & 17 & 8.5 & 16 & 9.8 & 1 & 2.8 \\
Italian bee & 2 & 1.0 & 2 & 1.2 & - & - \\
Caucasian bee & 74 & 37.0 & 62 & 37.8 & 12 & 33.3 \\
Carniolan bee & 36 & 18.0 & 26 & 15.9 & 10 & 27.8 \\
Anatolian bee (Muğla Ecotype) & 5 & 2.5 & 3 & 1.8 & 2 & 5.6 \\
Anatolian bee (Yığılca Ecotype) & 1 & 0.5 & 1 & 0.6 & - & - \\
\hline Total & $\mathbf{2 0 0}$ & $\mathbf{1 0 0}$ & $\mathbf{1 6 4}$ & $\mathbf{1 0 0}$ & $\mathbf{3 6}$ & $\mathbf{1 0 0}$ \\
\hline
\end{tabular}

According to our research, $63.0 \%$ of the analyzed enterprises fulfilled their queen demands solely from their own operations, $18.5 \%$ entirely from commercial enterprises, and $18.5 \%$ achieved their needs by both producing and purchasing their own queen bees. Moreover, income-oriented enterprises produce more queens and use less commercial queens than backyardpurpose enterprises (Table 10). In the study conducted by Güneşdoğdu and Akyol (2019) in Adana province, reported that $77.05 \%$ of the enterprises require the queen bee, from natural queen capscap for swarming, $13.66 \%$ by larvae transfer, larvae grafting, and $9.29 \%$ commercially purchased. In other survey studies, conducted in the Kemalpasa region of Izmir province, 94.35\% of beekeepers produce their own queen bees (Onuç et al., 2019), in Adıyaman, $48.8 \%$ of the enterprises stated that they produced their queen bee needs demands from their own colonies, while $27.9 \%$ stated that they achieved their queen bee needs by purchasing them from commercial queen bee producers (Özbakır et al., 2016). In Muğla province, $45 \%$ of bee breeders use natural swarm and 55\% use artificial swarm to reproduce their colonies (Öztürk, 2017), $90.8 \%$ of beekeepers in the province of Bingöl reproduce their colonies by division method, $6.9 \%$ by natural swarm, and $2.3 \%$ by commercial queen bee 
(Söğüt et al., 2019). In the Yığılca district of Düzce province, $8.2 \%$ of the beekeepers use artificially produced queen bees and $91.8 \%$ use the queen bees created naturally by the colony itself (Kekeçoğlu \& Rasgele, 2013). In Konya province, $46.67 \%$ of the enterprises produce the queen themselves, $37.78 \%$ buy them from the enterprises producing queen bees, $6.67 \%$ are from the beekeepers in the region and $8.88 \%$ are providing the queen bee through cooperatives and unions. (Çelik \& Turhan, 2014). In the province of Antalya, 36.84 of the migratory beekeeping enterprises breed the queen naturally and $44.74 \%$ by transferring larvae; It has been reported that $18.42 \%$ of them obtain their queen bee needs by purchasing them from enterprises that sell commercial queen bees (Akdeniz et al., 2015). In a study conducted in the provinces of the Eastern Black Sea region, $70.43 \%$ of the breeders produced their own queen bees and $24.50 \%$ purchased commercial queens (Kuvancl et al., 2017). Contrary to other provinces and our study results, it has been reported that $84.5 \%$ of beekeepers in Malatya purchased commercial queen bees (Kutlu \& Kılıç, 2020).

Table 10. Queen supply of the examined beekeeping enterprises

\begin{tabular}{lcccccc}
\hline & & General & \multicolumn{2}{c}{$\begin{array}{c}\text { Income-oriented } \\
\text { enterprises }\end{array}$} & \multicolumn{2}{c}{$\begin{array}{c}\text { Backyard beekeeping } \\
\text { enterprises }\end{array}$} \\
\hline Own production & $\mathbf{n}$ & Frequency, \% & $\mathbf{n}$ & Frequency, \% & $\mathbf{n}$ & Frequency, \% \\
Purchased & 126 & 63.0 & 107 & 65.2 & 19 & 52.8 \\
Both of them & 37 & 18.5 & 30 & 18.3 & 7 & 19.4 \\
\hline Total & 37 & 18.5 & 27 & 16.5 & 10 & 27.8 \\
\hline
\end{tabular}

In our research, we noticed that $60.6 \%$ of the investigated enterprises were affected by varroa parasites, 14.3 percent by brood diseases, 11.7 percent by nosema, and 9.8 percent by chalkbrood. Furthermore, it has been found that the frequency of varroa parasites is greater in backyard-purpose enterprises than in income-oriented enterprises (Table 11). In a study conducted in Adana, enterprises faced the highest number of Varroa destructor parasites $(87.6 \%)$ in their colonies, followed by brood diseases (11.2\%), nosema (7.1\%), and chalkbrood (4.7\%) (Güneşdoğdu \& Akyol, 2019). In another study conducted in Adana province, $78 \%$ of the enterprises were found to have varroa, $27 \%$ had nosema, $14 \%$ had brood diseases and 13\% had chalkbrood (Karahan \& Karacan, 2016). On the other hand, $63 \%$ of the enterprises in Konya are exposed to varroa, $22 \%$ to chalkbrood, $22 \%$ to brood diseases rot and $18 \%$ to nosema diseases and pests (Karahan \& Karaca, 2016). In Afyon province, the problem that beekeepers suffer the most is varroa with 76\% (Karahan et al., 2019). In the province of Bingöl, it has been reported that $86.2 \%$ of the beekeepers were exposed to varroa, $9.2 \%$ to brood diseases, $2.3 \%$ to nosema and $2.3 \%$ to chalkbrood (Söğüt et al., 2019). It has been determined that the primary problem of all the enterprises in bee health is Varroa destructor parasite. Varroa parasites are spread by bees by natural swarming or predatory activities of colonies. Moreover, the ability of drones to roam between colonies has also been reported as an important factor in the rapid spread of the varroa (Aydın, 2012).

Table 11. Diseases and pests encountered by the examined beekeeping enterprises

\begin{tabular}{lcccccc}
\hline & \multicolumn{2}{c}{ General } & \multicolumn{2}{c}{$\begin{array}{c}\text { Income-oriented } \\
\text { enterprises }\end{array}$} & \multicolumn{2}{c}{$\begin{array}{c}\text { Backyard beekeeping } \\
\text { enterprises }\end{array}$} \\
\hline & $\mathbf{n}$ & $\begin{array}{c}\text { Frequency, } \\
\text { \% }\end{array}$ & $\mathbf{n *}$ & $\begin{array}{c}\text { Frequency, } \\
\mathbf{\%}\end{array}$ & $\mathbf{n}^{*}$ & $\begin{array}{c}\text { Frequency, } \\
\mathbf{\%}\end{array}$ \\
\hline Varroa & 191 & 60.6 & 158 & 58.7 & 33 & 71.7 \\
Brood diseases & 45 & 14.3 & 38 & 14.1 & 7 & 15.2 \\
Nosema & 37 & 11.7 & 37 & 13.8 & - & - \\
Chalkbrood & 31 & 9.8 & 28 & 10.4 & 3 & 6.5 \\
Other & 11 & 3.5 & 8 & 3.0 & 3 & 6.5 \\
\hline Total & $\mathbf{3 1 5}$ & $\mathbf{1 0 0}$ & $\mathbf{2 6 9}$ & $\mathbf{1 0 0}$ & $\mathbf{4 6}$ & $\mathbf{1 0 0}$ \\
\hline
\end{tabular}

${ }^{\star}$ Multiple responses were considered. 
According to our findings, one of the most important concerns for enterprises in the industry is marketing, which accounts for $24 \%$ of all concerns. After the marketing problem, the major problems faced by enterprises are accommodation (17.7\%), diseases and pests $(15.7 \%)$, safety $(15.7 \%)$, transportation (10.4\%), and pesticide applications (7.1\%). While the marketing problem is foregrounded with a share of $25.3 \%$ in income-oriented enterprises, it has been determined that the biggest problem in enterprises engaged in production for backyard purposes is honeybee diseases and pests with a share of $19.3 \%$ (Table 12). It has been determined that the most important problem encountered by beekeepers in Adana is the accommodation problem, besides, in the regions where the beekeepers go, there are important problems such as forager bee deaths caused by pesticides, theft incidents, transportation problems, demanding rent for the land and fire (Güneşdoğdu \& Akyol, 2019). According to a survey performed by Onuç et al. (2019) in the Kemalpasa region of Izmir, the most fundamental challenge in beekeeping is difficulties in marketing bee products, with a rate of $32.08 \%$. This is followed by the absence of effective treatments against diseases and parasites with a rate of $26.42 \%$, the use of intensive pesticides with a rate of $13.21 \%$, the inability to sufficiently introduce the benefits of bee products to consumers with a rate of $13.21 \%$, and the inability to standardize bee products with a rate of 5.66\%. Öztürk (2017), questioned beekeepers in Muğla province Ula district what the most significant difficulty of beekeeping in Turkey is, $70 \%$ of the producers responded that they had marketing challenges due to low honey prices and that they had accommodation problems in migratory beekeeping. Other concerns include high input prices, limited supports, the varroa problem, a lack of fuel support for transportation, placing a colony in the same place above its capacity, and bee mortality caused by pesticides. In the Konya province, $57.78 \%$ claimed difficulty with marketing, $22.22 \%$ in production, and $20.00 \%$ with disease and pest control (Çelik \& Turhan, 2014). In Bitlis province's Hizan district, $43 \%$ of beekeepers reported pesticide problems, $32 \%$ reported problems with place availability and accommodation, $13 \%$ reported problems with foreign migratory beekeepers, 7\% reported theft, and $5 \%$ reported problems with the headmen in their accommodation (Kutlu et al., 2016). Although there are variations in the rankings in terms of regional differences and priorities, the findings we obtained in our study are similar to the findings given in the literature information. In general, beekeepers highlight marketing, diseases and pests, bee fatalities due to intensive pesticide application, and difficulties encountered during accommodation and transportation.

Table 12. The main problems faced by the examined beekeeping enterprises in the sector

\begin{tabular}{lcccccc}
\hline & \multicolumn{2}{c}{ General } & \multicolumn{2}{c}{$\begin{array}{c}\text { Income-oriented } \\
\text { enterprises }\end{array}$} & \multicolumn{2}{c}{$\begin{array}{c}\text { Backyard beekeeping } \\
\text { enterprises }\end{array}$} \\
\hline Accommodation & $\mathbf{n}$ & Frequency, $\%$ & $\mathbf{n} *$ & Frequency, \% & $\mathbf{n} *$ & Frequency, \% \\
Transportation & 87 & 17.7 & 79 & 18.2 & 8 & 14.0 \\
Security & 51 & 10.4 & 48 & 11.1 & 3 & 5.3 \\
Usage of Pesticides & 77 & 15.7 & 69 & 15.9 & 8 & 14.0 \\
Diseases and Pests & 35 & 7.1 & 29 & 6.7 & 6 & 10.5 \\
Packaging & 77 & 15.7 & 66 & 15.2 & 11 & 19.3 \\
Marketing & 10 & 2.0 & 9 & 2.1 & 1 & 1.8 \\
Other & 118 & 24.0 & 110 & 25.3 & 8 & 14.0 \\
\hline Total & 36 & 7.3 & 24 & 5.5 & 12 & 21.1 \\
\hline
\end{tabular}

${ }^{*}$ Multiple responses were considered.

\section{Conclusion}

The marketing problem is one of the most serious issues confronting beekeeping operations in Turkey. In particular, the presence of imitation and adulteration bee products in the market causes the price stability of the products to not be ensured, and therefore the products produced by the enterprises cannot be offered at their ideal value. The Ministry of Agriculture and Forestry's identification of counterfeit and adulterated products and enterprises on the market, as well as the application of regulatory sanctions on these enterprises, helped beekeepers breathe a little easier. The establishment of honey cooperatives through Beekeepers' Unions and assuring honey price stability by governmental organizations are among the primary recommendations brought to the table by beekeepers in the marketing of bee products. Another problem faced by enterprises is the inability to effectively control honey bee diseases and pests. Moreover, diseases and pests cause a significant amount of colony losses and yield losses for enterprises. Furthermore, it has been noticed that the effectiveness levels of licensed treatments available on the market do not satisfy the 
requirements of enterprises. In particular, the potential of beekeepers to turn to unlicensed drugs due to commercial concerns will cause residue problem in products. It is critical to identify the efficacy levels of licensed treatments with different active components on the market, as well as the rates of parasite resistance to these treatments in particular. Communication should be established between relevant government institutions and organizations, non-governmental organizations, and universities. Pesticide application in agricultural products is another threat to enterprises, since it causes a decrease in colony populations, yield losses, and residues in bee products. Pesticide treatments should be carried out during times when honey bees do not flight activity, with the cooperation of beekeepers, non-governmental organizations, and Agriculture and Forestry Departments. It is required to produce various bee products, such as apiteraphy products, other than honey in order for the companies to be financially successful. The positive effects of apitherapy products on human health make bee products consumption more paying attention by the day. It is obvious that strategically guiding breeders to alternative bee products with the appropriate support policies, would make major contributions to the country`s economy. On the other hand, solving the problem of quality breeding queens with breeding studies, more effective work of non-governmental organizations, dissemination of vocational training, increasing state supports and inspections are other issues that are expected to be solved by enterprises.

\section{References}

Akdeniz, G., Kılıçin, T., \& Cınbırtoğlu, Ş. (2015). Gezgin Arıcılık İşletmelerinin Ana Arı Tercihleri Üzerine Bir Araştırma. IX. Ulusal Zootekni Bilim Kongresi.

Aktürk, D., \& Aydın, B. (2019). Structural Characteristics of Beekeeping Enterprises and Beekeeping Activites in Çanakkale Province. Turkish Journal of Agriculture-Food Science and Technology, $7(10), 1618-1628$.

Anonymous, (2021a). TÜiK, Turkish Statistical Institute, http://www.tuik.gov.tr

Anonymous, (2021b). FAO, Food and Agriculture Organization of the United Nations, https://www.fao.org/faostat/en/\#home

Aydın, L. (2012). Varroa ilaçları ve Kontrol Programı. International III. Muğla Beekeeping and Pine Honey Congress.

Borum, A. E., (2017). Güney Marmara Bölgesinde Arıcılık Anket Çalışması. Uludağ Arıcılık Dergisi, 17(1), 24-34.

Çelik, Y., \& Turhan, İ. (2014). Konya İlinde Arıcılık İşletmelerinin Yapısal Özellikleri. Uludağ Arıcılık Dergisi, 14(1), 15-25.

Çevrimli, M., \& Sakarya, E. (2018). Arıcılık İşletmelerinin Yapısal Özellikleri ve Sorunları: Ege Bölgesi Örneği. Eurasian Journal of Veterinary Sciences, 34(2), 83-91.

Emir, M. (2015). Türkiye'de Arıcıların Sosyo-Ekonomik Yapısı ve Üretim Etkinliği (Unpublished doctoral dissertation). Ondokuz Mayıs
Üniversitesi Fen Bilimleri Enstitüsü Tarım Ekonomisi Anabilim Dalı.

Free, J. B. (1993). Insect Pollination of Crops. Academic Press.

Güler, A. (2006). Bal Arısı. OMÜ Ziraat Fakültesi.

Güneşdoğdu, M., \& Akyol, E. (2019). A Survey Study to Determine the Structure of Beekeeping in Adana Province. Turkish Journal of Agriculture - Food Science and Technology, 7(12), 2030- 2037.

Kadirhanoğulları, í. H., Karadaş, K., \& Külekci, M. (2016). Iğdır illi Arıcıların Sosyo-Ekonomik Durumu. Uludağ Arıcılık Dergisi, 16 (1), 2-11.

Karahan, A., \& Karaca, İ. (2016). Adana ve Konya İlerindeki Arıcılık Faaliyetleri ve Koloni Kayıpları. Süleyman Demirel Üniversitesi Fen Bilimleri Enstitüsü Dergisi, 20(2), 226-235.

Karahan, A., Acar, İ., Özşahin, R., \& Karaca, İ. (2019). Afyonkarahisar ili Arıcılık Faaliyetleri. II. Uluslararası Tarım Kongresi.

Kaufman, P. B. (1989). Biology and Importance. Haber\&Row Publisher. Kekeçoğlu, M., \& Rasgele, P. (2013). Düzce ili Yığılca İlçesindeki Arıcılık Faaliyetleri Üzerine Bir Çalışma. Uludağ Arıcılık Dergisi, 13(1), 23-32.

Kekeçoğlu, M., Rasgele, P. G., Acar, F., \& Kaya, S. T. (2013) Düzce İlinde Arıcılığın Yapısı Ve Arıcılık Faaliyetleri Üzerine Bir Araştırma. Düzce Üniv. Bilim Tekn. Derg., 2, 1-15.

Kutlu, M. A. (2014). Gaziantep illi Arıcılık Düzeyinin Saptanması, Sorunları ve Çözüm Yolları. Türk Tarım ve Doğa Bilimleri Dergisi, 1(4), 481-484.

Kutlu, M. A., Özdemir. F. A., \& Kılıç, Ö. (2016). Hizan İlçesindeki Arıcılık Faaliyetleri Üzerine Bir Araştırma. Mustafa Kemal Üniversitesi Ziraat Fakültesi Dergisi, 21(1), 197-206.

Kutlu, M. A., \& Kılıç, Ö. (2020). Elazığ İli (Türkiye) Arıcılığının Sürdürülebilirliği Üzerine Bir Çalışma. ADYÜTAYAM, 8(1), 38-49.

Kuvancı, A., Yılmaz, F., Öztürk, S. H., Konak, F., \& Buldağ, M. (2017). Doğu Karadeniz Bölgesi Arıcılığına Genel Bakış. Arıcılık Araştırma Dergisi, 9(2), 47-55.

Onuç, Z., Yanar, A., Saner, G., \& Güler, D. (2019). Arıcılık Faaliyetinin Ekonomik Yönü Üzerine Bir Analiz: İzmir-Kemalpaşa İlçesi Örneği. Ege Üniversitesi Ziraat Fakültesi Dergisi, 56(1), 7- 14.

Özbakır, G. Ö., Doğan, Z., \& Öztokmak, A. (2016). Adıyaman İli Arıcılık Faaliyetlerinin İncelenmesi. Harran Tarım ve Gıda Bilimleri Dergisi, 20(2), 119- 126.

Öztürk, A. İ. (2017). Muğla İli Ula İlçesi Arıcılığının Bazı Teknik Özelliklerinin Belirlenmesi. Hayvansal Üretim 58(2), 52-57.

Seğmenoğlu, N. (2018). Adana İlinde Arıcılığın Genel Yapısı ve Arıcılık Faaliyetleri (Unpublished Master's Thesis). Fırat Üniversitesi, Sağlık Bilimleri Enstitüsü, Zootekni Anabilim Dalı.

Sert, D. (2017). Arıcılık Faaliyetinin Ekonomik Analizi: Isparta İli Örneği (Unpublished Master's Thesis). Süleymen Demirel Üniversitesi, Fen Bilimleri Enstitüsü.

Seven, İ., \& Yeninar, H. (2010). Elazığ yöresindeki arıcılık işletmelerinin hastalık, parazit ve zararlılar yönünden incelenmesi. Veterinary Sciences, 5(2), 52-66.

Söğüt, B., Şeviş, H. E., Karakaya, E., \& İnci, H. (2019). Arıcılık İşletmelerinde Mevcut Durum, Temel Sorunlar ve Çözüm Önerileri Üzerine Bir Araştırma (Bingöl İli Örneği). Uludağ Arıcılık Dergisi, 19(1), 50-60.

Tabur, Z., \& Gül, A. (2019). Uşak İlinde Arı Yetiştiricilerinin SosyoEkonomik Durumu ve Arıcılığın Teknik Özelliklerinin Belirlenmesi. Mustafa Kemal Üniversitesi Tarım Bilimleri Dergisi, 24(2), 146-152.

Turhan, F. (2019). Sivas illinde Arıcılık Faaliyetinde Bulunan İşletmelerin Mevcut Yapısı ve Sorunları (Unpublished Master's Thesis). Çukurova Üniversitesi, Fen Bilimleri Enstitüsü, Tarım Ekonomisi Anabilim Dalı.

Uzundumlu, A., Aksoy, A., \& Işık, B. (2011). Arıcılık İşletmelerinde Mevcut Yapı ve Temel Sorunlar; Bingöl ilii Örneği. Atatürk Üniversitesi Ziraat Fak. Dergisi, 42(1), 49-55. 